\title{
Graduate School Services: Basis for an Improvement Plan
}

\author{
Jocelyn L. Absolor*, Joel C. Ferrer, Imelda N. Binay-an \\ Ilocos Sur Polytechnic State College, Philippines \\ *jocelynlabsolor@gmail.com
}

\begin{abstract}
The study aimed to determine the students' level of satisfaction on the services of the Graduate School of Ilocos Sur Polytechnic State College along professional services, school facilities, and learning environment. It further determined the profile of the respondents in terms of age, sex, civil status, position, employment status, number of years in teaching and type of school employed in. The profile was correlated to their level of satisfaction. The weaknesses of the services were identified as basis in the development of an Improvement Plan. The study is a descriptive research employing correlational and developmental methods. A sample size of 120 graduate students were selected randomly with a questionnaire as an instrument in obtaining data that were treated using frequency count and percentage, simple bi-variate correlation, and Cronbach Alpha. Results show that the profile of the respondents are of varying background. The three services considered in the study obtained a high satisfaction level. Years of teaching is a determinant of satisfaction on professional services while position shows significant effect on their satisfaction of school facilities and learning environment. The accessibility of books and computers in the library and dormitories were identified as areas that require improvement.
\end{abstract}

Keywords: Graduate School services, professional services, school facilities and learning environment

\section{INTRODUCTION}

Graduate education is at the apex of the educational system. In the field of education, graduate studies is one of the more effective means of improving capacities of education professionals who aim to contribute to the continued improvement of teaching and learning in the classrooms, delivery of student services, and management of educational programs[1].This stipulation defines the role of the Graduate School it needs to perform towards graduate students. Its role, therefore, is important as it nurtures individuals to grow academically and professionally. The role of Higher Education Institutions(HEIs) where students chose to pursue their studies is deemed important in offering the best services for its clientele. Classified as an Advanced Higher Education, therefore, it is duty bound to provide clientele satisfaction on the services offered by its unit.

Affirming the statement above, Mc Gowen [2] states that the main goal of any higher education institution is to sustain a learning society that can understand and deal appropriately with itself and the rest of the world.
Adding to this, Vidalakis et al.,[3] emphasizes that the achievement of that goal cannot be possible without the efficiency and effectiveness in the provision of the services provided by the higher education institution. Most higher education institutions strive to achieve the efficiency and effectiveness in their educational services by investing wisely on issues such as facilities, human resources, education system and student.

Athiyaman [4] recognizes that institutions of higher education are increasingly realizing that they are part of the service industry and are putting greater emphasis on student satisfaction as they face many competitive pressures. Maintaining and improving students' satisfaction have been considered important goals of education and universities [5], with the assumption that student satisfaction is indicative of institutional effectiveness [6].

As confirmed by Navarro et al., [7],Higher Educational Institutions(HEIs) are increasingly recognizing that higher education is a service industry. As service organization, higher educational institutions are dealing with a same situation which places greater 
emphasis on meeting the expectations and needs of their customers.

Elliot and Healy [8] indicated that student's satisfaction is a short-term attitude that results from the evaluation of their experience with the education service received. It should be highlighted that most of the studies on this issue were carried out within the context of analyzing student's satisfaction for the main services or the core business offered by universities. On the other hand,Gbadosami \& De Jager [9] maintain that measuring and assuring the quality of services provided by such important stakeholders as students, staff, and employers is of key importance for universities. Students' satisfaction with their educational experience, like customer satisfaction, is the result of a complex set of factors. Understanding what those factors are and how they combine to influence satisfaction is critical to educators who believe that student satisfaction in addition to learning is a desired outcome of their efforts [10].

According to Oliver[11] satisfaction involves an evaluative, affective, or emotional response. In his book, he defined satisfaction/dissatisfaction as "the consumer's fulfillment response, the degree to which the level of fulfillment is pleasant or unpleasant" [12]. Therefore, satisfaction is the customer's overall judgment of the service provider [13]. Crompton and MacKay [14] stated that, "Satisfaction is a psychological outcome emerging from an experience, whereas service quality is concerned with the attributes of the service itself".

Browne[15] used three dependent measures to gauge students' satisfaction on the quality of college services.As a result, it indicated that perceived quality of the educational offering and service quality are described with different degree of satisfaction. Grossman [16], determined students' satisfaction by evaluating of the quality of coursework, curriculum activities and other factors related to the university and students could be treated like a customer or a client within the college and in that case, the college serves the students on a better priority to fulfill their expectations and needs. Mostly, when the service quality provided meets students expectations, they are likely to be satisfied in their educational institutions, or they will be very satisfied when the service is beyond their expectations, or will be completely satisfied when they receive more than they have expected.

The rise in the internationalization and globalization of higher education in particular, the rapid development of cross border higher education, has underlined an urgent need to establish robust frameworks for quality assurance and the recognition of qualifications [17]. Its actions in this area focus on providing information and capacity to empower higher education stakeholders to make better informed decisions in the new world of higher education. This initiative aims to provide information to protect students from inadequate learning resources and low-quality provisions.

Organizations, irrespective of their industry, focus on the quality of services provided because of its integral role in developing competitive advantage and in attracting new and retaining existing outcomes [18].Similarly, within the higher education context, provision of quality services is one of the most important priorities of educational institutes around the world [19].

Education sector is expanding very rapidly all over the world in recent years. Globalization and digital revolution has created a demand for new and varied disciplines in education. The cost of providing education has gone up manifold due to better teaching methodologies and learning instruments with rising inflation worldwide. The brisk increase number of institutions in higher education has led to an intense competition. Number of new institutions has been established and enrolment is also on the rise[20].Students can get information easily and instantly due to the advancement in technology and globalization. In this competitive environment only those institutions which are providing quality education and constructive environment to their students can excel. These factors can influence their choice of admission. Such factors can satisfy students to their institutions and can affect their decision to enrol in their programs.

ISPSC Graduate School, like any other advanced higher education providers, performs its mandate to offer quality education. The existing program offerings are accredited by AACUP. The different areas indicated in the instrument prescribed by the accrediting body are continuously improved to comply with their recommendations.

Apart from this mechanism devised to evaluate the College's programs, this research will try to look into the perception of the clientele how Graduate School services are rendered to them through their assessment.

It is from this premise that this study was conducted. This study brings to an understanding on how student will have more opportunity to support their continued enrolment into advanced higher educational institutions and on how well the educational programs and services met students' expectations.

\subsection{Literature Review}

Determining and assessing student satisfaction based on their perception of the quality of a university's services may not be an easy task, but it can be very 
helpful for the universities to build a strong relationship with their existing and potential students[21].

The framework developed by Jurkowitsch, et al. [22] aims to assess students' satisfaction. In this framework, service performance, university performance, relationships with student, university standing work as antecedents of satisfaction and promotion works the successor. Later, Deshields et al.,[23] used a satisfaction model and Herzberg's two factor theory to examine the determinants of student satisfaction with education. Their study disclosed that faculty performance and classes were the key factors which determined the quality of college experience of students. In the same vein, Alves and Raposo[24] developed a conceptual model to assess students' satisfaction in 2010. According to the model student's satisfaction in higher education is determined by institute's image, student expectations, perceived technical quality, functional quality and perceived value. These influences can be identified directly or indirectly through other variables.

\subsubsection{Professional Services}

Wilkins \& Balakrishnan [25]identified quality of lecturers, quality of physical facilities and effective use of technology as key determinant factors of student satisfaction. Factors associated with teaching and learning were the most important factors that could have influenced student's level of satisfaction. Therefore, higher educational institutions should provide quality teaching and learning services (Sapri et al.[26].Lectures, attainment of knowledge, class notes and materials and classroom delivery were the most important aspects of the core services provided by higher educational institutions[27] and [28].

The study of Kanan \& Baker [29] examined the influence of international schools on adolescent local students considering the following dimensions; individual and collective identity, career aspiration, and type and location of the university they aspire to enrol in. The results indicated that students enrolled in international, magnet and public schools in Qatar have different perceptions and choices of career. The study of Navarro [7] raised two objectives. It looked into the determinants of satisfaction on the degree programs and the relationship between the satisfaction experienced by the students enrolled in the programs and their loyalty to the institution that offers the courses. Results indicated the importance of the teaching staff, the teaching methods and course administration in achieving satisfaction and loyalty. Palacio, et al., [30] investigated the impact of university image on students' satisfaction. The study found that university image of Spanish University System make a significant impact on students' satisfaction. Malik, et al. [31] studied the impact of teachers' satisfaction with job dimensions on perceived organizational commitment in public sector universities of Pakistan. It also attempted to look into the commitment of the teachers towards their university and their satisfaction to their job. Result showed that satisfaction with work-itself, quality of supervision and pay satisfaction played significant positive influence on university teachers. Teachers manifested high degree of organizational commitment and satisfaction with workitself, supervision, salary, coworkers and opportunities for promotion. Pathmini, et al [32] examined the level of service quality and its impct on students' satisfaction in the Faculty Management Studies(FHM). Results indicated that only three factors are significant predictors to students' satisfaction and they are; empathy, content and reliability of the service process. With this result, the study recommended that these factors should be given consideration.

The exploration of Yu and Dean [33] on the role of emotion, cognitive components and affective components on satisfaction were considered. As a result, affective components are predictors of customer loyalty. Wiers-Jenssen et al. [34] on the other hand, examined student satisfaction in the context of students' learning experience. It revealed that quality of teaching in terms of academic and pedagogy appeared to be a crucial determinant of student satisfaction. The study also demonstrated that the social climate, aesthetic aspects of physical infrastructure and the quality of services from the administrative staff, composition, content and relevance of curriculum, quality of, and access to leisure activities should be given a degree of consideration in improving students' satisfaction and in the provision of learning opportunities.

The investment theory of students' satisfaction of Hatcher, Prus, Kryter and Fitzgerald[35] illustrated the behavior of students' satisfaction with academic performance from investment point of view. According to the theory, student perceives their time, energy and effort as investment and seek a return from that. Accordingly, students will satisfy if they are rewarded in relation to the investment they made[36].

The investigation of Farahmandian, et al.[37]on the levels of satisfaction and its relationship to quality of service offered by the International Business School, University Teknologi Malaysia indicated that most of the students were satisfied. Further, the study advances that academic advising, curriculum, teaching quality, financial assistance, tuition fee and university facilities have significant impact on students' satisfaction. In the same vein, Khan [38] discussed the impact of service quality on levels of students' satisfaction at Heailey College of Commerce, Pakistan. Findings show that Reliability, Assurance, Responsiveness and Empathy are the dimensions that show effect on satisfaction while Tangible showed insignificant effect. was having an insignificant relation with student satisfaction. 


\subsubsection{School Facilities}

The study of McGowen [2] explored the possible relationship between school facility conditions and school outcomes such as student academic achievement, attendance, discipline, completion rate and teacher turnover rate.School facility condition for the participating schools was determined by the Total Learning Environment Assessment (TLEA).His study disclosed that achievement, attendance and completion rate measures were not found to be significant in relation to school facility conditions as measured by the TLEA ; discipline, or behavior, was found to be significantly related to the TLEA. and, teacher turnover rate was found to be related to the TLEA.

Gruber et al.,[39] emphasized that apart from investing on the academic facilities to upgrade the quality of the academic services provided, the universities also invest on those facilities in order to meet the academic needs of the students and make their experience in the university worthwhile. Academic facilities are one of the important elements that must be present to ensure that the students, who are legal clients of these higher education institutions, are satisfied and have better academic services for better experience. Thus, the relationship between academic facilities and student satisfaction cannot be easily separated or overlooked. Contrary to this, Douglas et al.,[40]measured students' satisfaction at Faculty of Business and Law, Liverpool John Moores University Malaysia. The study found that physical facilities of university are not significantly important with regards to students' satisfaction but it works as key determinant of students' choice in selecting universities

The way academic facilities have been organized and established provide the place where the whole academic process is being provided. The better the academic facilities lead to better education process and its overall quality [41]

A growing body of research has found that school facilities can have a profound impact on both teacher and student outcomes. With respect to teachers, school facilities affect teacher recruitment, retention, commitment, and effort. With respect to students, school facilities affect health, behavior, engagement, learning, and growth in achievement. Thus, researchers generally conclude that without adequate facilities and resources, it is extremely difficult to serve large numbers of students with complex needs[42].The correlation between building age and student achievement has been found to be significant in Texas studies. O'Neill and Oates [43] report that building age had the highest correlation with student achievement of all building factors investigated in a 1999 study of middle schools in Central Texas.
Facility appraisal should be one of the many roles assumed by educational leaders. Maiden \& Foreman [44] claim that school administrators should be "armed with a general understanding of the relationship between various physical features of a facility and the learning climate". It stands to reason that facility evaluation would warrant equitable scrutiny and effort to that of ventures into pedagogy and curriculum.

A comparative study looking into the satisfaction of UK and US students in higher and its influential factors were examined by Mai[45].Her study disclosed that the over-all impression of the school, overall impression of the quality of the education, teachers expertise and their interest in the subject, the quality and accessibility of IT facilities and the prospects of the degree furthering students careers were the most influential predictors of the students satisfaction.

The most comprehensive definition of satisfaction has been offered by Kotler and Keller[46] who define satisfaction as person's feeling of pleasure or disappointment which resulted from comparing a product's perceived performance or outcome against his/ her expectations while Rai [47] perception is defined as consumer's belief, concerning the service received or experienced.

\subsubsection{Learning Environment}

Learning environment can be tangible and intangible services that may create impact to students' acquisition of learning. In consonance to this statement, the study of Yusoff et al,[48] included 12 factors that significantly influence students' satisfaction in Malaysian higher education institution. These variables include professional comfortable environment, student assessment and learning experiences, classroom environment, lecture and tutorial facilitating goods, textbooks and tuition fees, student support facilities, business procedures, relationship with the teaching staff, knowledgeable and responsive faculty, staff helpfulness, feedback, and class sizes make significant impact on students' satisfaction. The study revealed that year of study, program of study and semester grade show significant effect on student support facilities and class sizes. Accordingly, understanding these factors could help educational institutions to better plan their strategies.

The study of Lei [49] indicates that physical learning environment affects how students experience teaching. When no attention has been paid to the quality of the physical learning environment, students are more dissatisfied with the quality of teaching. More focus should be put on the development of learning environments to make them better support learning.

According to Cheng and Tam [50], "Education quality is a rather vague and controversial concept" 
while Alves and Raposo [24], found that positive perceptions of service quality have a significant influence on students' satisfaction and thus satisfied students would attract more students through word-ofmouth communication. This statement means that once students are satisfied with the service quality, these students will attract more students through word-ofmouth communication and at the same time this will be a marketing channel for the university or higher educational institutions in promoting the university.

HEIs need to provide learning environments that maintain high standards, while they also need to facilitate the learning of an increasingly diverse group of learners[51].Thus, the learning environment is multidimensional, with a range of inherent factors potentially influencing students' learning and their satisfaction with the learning experience.

Thygesen [52] examined the intrinsic relationships between five learning environment scales embedded within one measure; and examined the associations between each of these scales and an overall measure of education program satisfaction. Findings show that higher education program satisfaction was significantly associated with higher scores on "clear goals and standards," "emphasis on independence" and "good teaching.

Accordingly,student's different types of experiences and characteristics affect satisfaction level. Academic experiences and faculty preparedness affect directly campus services do not affect significantly [53]. Students' experience of acceptance influences multiple dimensions of their behavior but that schools adopt organizational practices that neglect and may actually undermine students' experience of membership in a supportive community[54]. It is often hard to identify actions or behaviors as correct or faulty, making it hard to provide an adaptive support to students who do not learn well with these environments [55].

\subsection{Objectives}

The study aimed to determine the level of satisfaction of the Graduate students on the Graduate School services of the Ilocos Sur Polytechnic State College as basis for the formulation of an Improvement Plan. Specifically, it sought answers to the following problems: 1.What is the profile of the respondents in terms of: age; sex; civil status; position; employment status; number of years in teaching; and type of school employed in? 2.What is the level of satisfaction of the respondents along: Professional Services; School Facilities;and c.Learning Environment? 3. Is there a significant relationship between the profile and the level of satisfaction of the students along: a. Professional Services, b. School Facilities,and c. Learning Environment?. 4. What are the strengths and weaknesses of the Graduate School services? 5. What Improvement plan can be proposed to improve the services of the Graduate School of ISPSC?

\subsection{Time and Place}

This study was conducted at Ilocos Sur Polytechnic State College,Tagudin and Sta.Maria Campuses covering the academic Year 2019-2020.These two identified campuses of ISPSC are the only campuses offering Advanced Higher Education.

\section{METHODS}

\subsection{Research Design}

This study made use of descriptive, correlational and developmental research design. The profile of the respondents,level of satisfaction, strengths and weaknesses and validity of the output employed descriptive.The correlational design dealt on the relationship of the variables under profile and the level of their satisfaction.This research also employed developmental as this study produced an Improvement Plan as an output.

\subsection{Population and Locale}

The respondents of this study were the 120 graduate students from the two campuses of Ilocos Sur Polytechnic State College,Tagudin and Sta.Maria Campuses respectively. Using GPOWER and applying the following input parameters, effect size 0.3 (moderate); alpha error probability 0.05 ; power 0.95 arriving to a sample size of 120 thus distributed as 60 samples from Sta.Maria and 60 samples from Tagudin. Samples were identified randomly.

\subsection{Research Instrument}

To gather the necessary data to answer the queries raised in this study, a modified questionnaire was utilized. The first dimension was lifted from the QCE instrument used to evaluate faculty members teaching performance in all SUCs in the Philippines for their NBC 461. Said items are believed to be applicable in the ISPSC setting while the items under the second and third dimensions were constructed by the researcher. Because of the modifications done,it was piloted and obtained a 0.7 reliability.

\subsection{Data Gathering Procedure}

The researcher obtained the data and information through the use of a questionnaire which is composed of two parts. First part of which elicited the profile of the respondents while the second part obtained the items pertaining to the services of the Graduate School such as 
Professional Services, School Facilities and Learning Environment. Prior to the floating of the questionnaire the instrument were validated and pilot tested to get its reliability result of 0.7 . The researcher personally floated and retrieved the questionnaire from the graduate students enrolled for the Academic Year 20192020 in the two campuses,Sta.Maria and Tagudin.

\subsection{Statistical Treatment of Data}

The following statistical tools were employed in this research:Frequency Count and Percentage employed in describing the profile of the respondents,satisfaction level and strengths and weaknesses. Simple bi-variate correlation was utilized to determine the significant relationship between the respondents' profile and the students' level of satisfaction on the Graduate School Services. Cronbach Alpha was employed to compute the reliability index of the questionnaire.

\subsection{Data Categorization}

Level of Satisfaction on Graduate School Services

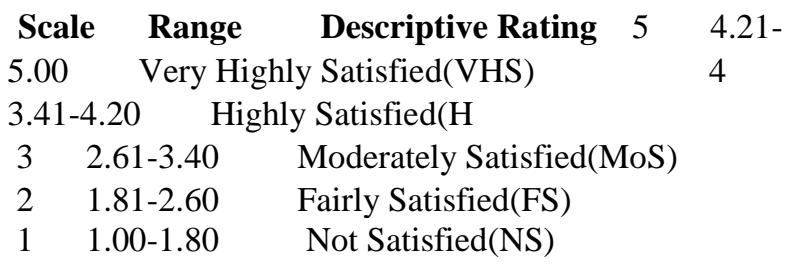

Strengths and Weaknesses of Graduate School Services

$\begin{array}{cl}\text { Range } & \text { Descriptive Rating } \\ 3.41-5.0 & \text { Strengths } \\ 1.00-3.40 & \text { Weaknesses }\end{array}$

All indicators having 3.41 mean value and above are strengths while indicators having 3.40 mean value and below are weaknesses. The weaknesses served as benchmark in the development of the Improvement Plan for Graduate School Services

\section{RESULTS AND DISCUSSION}

Figure 1 discloses the age of the respondents. It is evident that most of the respondents 58 or $48 \%$ belong to the age bracket 21-25 followed by the age bracket 2630 with 28 or $23 \%$.It is also noted in the result that the least distribution is on age bracket $41-45$ with 1 or $1 \%$.This result implies that majority of the students in the Graduate School are fresh graduates from college. Their pursuance of Master's degree at a very early pace of their life could be consistent with RA 10912, otherwise known as the "Continuing Professional Development(CPD) Act of 2016, which declares that it shall be "the policy of the State to promote and upgrade the practice of professions in the country. Towards this end, the State shall institute measures that will continuously improve competence of the professionals in accordance with the international standards of practice. But more than this, young graduates enrol for the purpose of keeping pace with the demand of global competitiveness as emphasized I RA No. 7722 known as Higher Education Act of 1994 and CHED Memorandum No.36,s.1998[56].

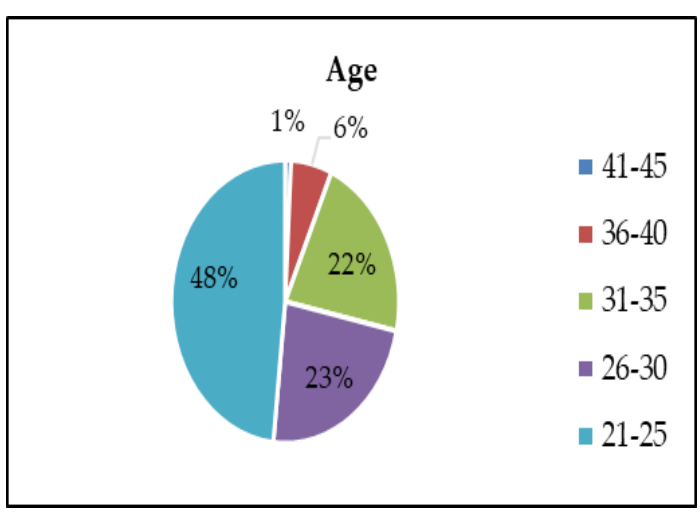

Fig.1 Distribution of Age of the Respondents

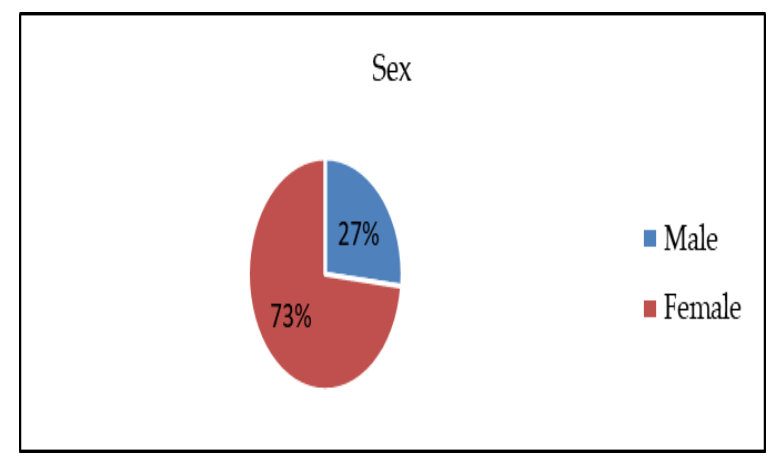

Fig.2 Distribution of Sex of the Respondents

As reflected on figure 2, male respondents are dominated by female with 88 or $73 \%$ compared to male with only 32 or $27 \%$.The result indicates that there are more female who are interested to pursue their master's degree.

This result backs up the data provided by The Independent that Higher Education in UK revealed that young women are 36 present more likely to apply to university than their male peers[57].The article further discloses that it's not just the UK but even countries all over the world are seeing an increase in female applications. Panama, Sri Lanka, Argentina, Cuba, Jamaica and Brunei - to name a few - have some of the highest female to male ratios in higher education. In Malaysia, more than 64 percent of university enrollments are female - a number which has increased consistently for years.

It can be gleaned on figure 3 that majority of the respondents are single with 75 or $63 \%$ followed by married with 39 or $32 \%$ and only six or 6 or $5 \%$ of the respondents indicates a separated status. 


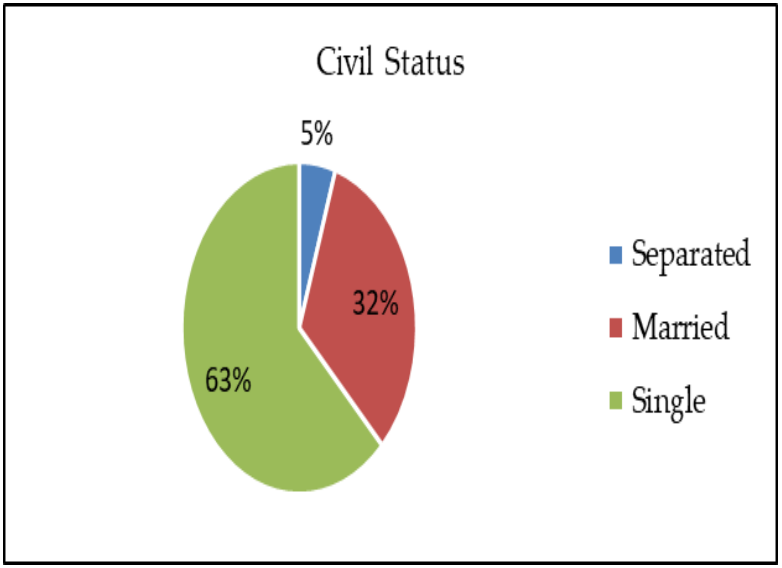

Fig.3 Civil Status

This result implies that since the age bracket of the respondents is on the age 21-25 most likely this age is not yet a marrying age as they chose to struggle with their post graduate study over married life. This result contradicts the result of the study conducted by Naungayan [58] which revealed that five out of six or $83.33 \%$ of the teacher-respondents are married while only one or $16.67 \%$ is single denoting that most of the teachers were married and have other important commitments outside school. It was the same findings obtained by Escalona [59] whose respondents are mostly married.

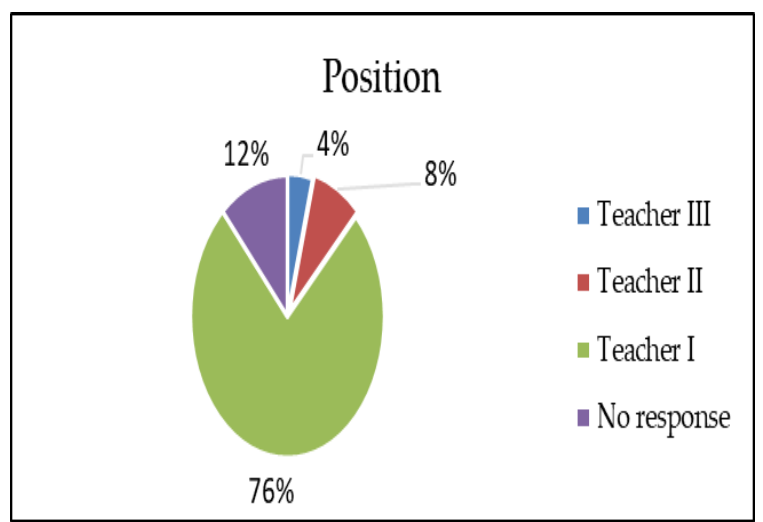

Fig.4 Position

Figure 4 shows the position of the respondents in their respective workplaces. It can be noted that most of them 91 or $75 \%$ are occupying Teacher 1 position and only 5 or $4 \%$ are Teacher III.This result implies that due to their newness in the teaching profession as their age indicates they are not yet promoted or did not yet apply for promotion as promotion requires higher qualifications.

This result opposes the result of the study of Naungayan[58] whose study reveals that most of his respondents are already Teacher III . None of the teacher-respondents is at the bottom teaching position, Teacher I.

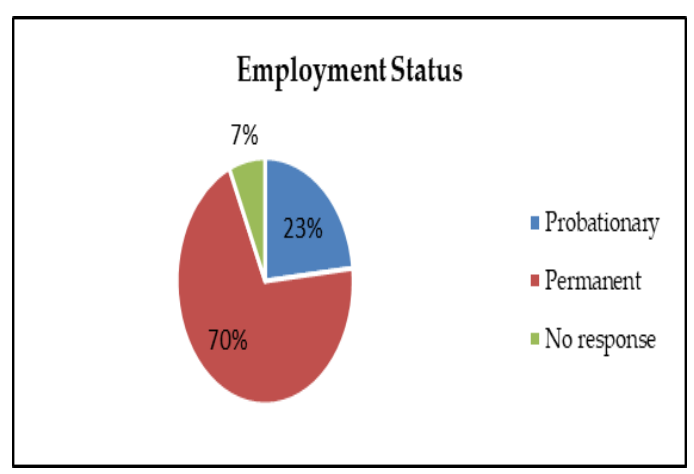

Fig.5 Employment Status

Figure 5 reveals that 84 or $70 \%$ of the respondents are occupying permanent positions while 28 or $23 \%$ are still probationary in their workplace and $7 \%$ of them did not respond as to their employment status and it is assumed to be unemployed when the study was conducted.

Findings imply that though still young in the profession they are already holder of permanent appointment in the Department of Education(DepEd). This could be attributed to the fact that under k-12 Curriculum, with the addition of senior high school, the Department of Education(DepEd) hired more teachers to teach in the Senior High School which was posted in their sites[60].

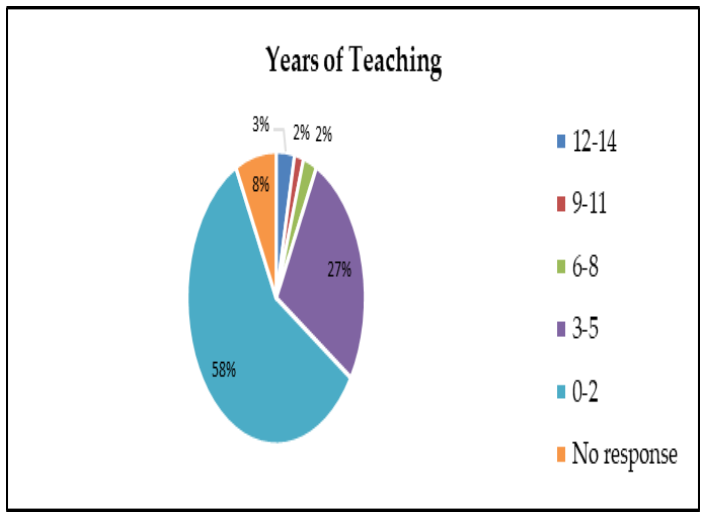

Fig.6 Years of Teaching

Figure 6 presents the years of teaching of the respondents. It is very interesting to note that 70 or $58 \%$ have only two years in the teaching field followed by 32 or $27 \%$ whose teaching experiences is ranging from three to five years. Strikingly, 3 or $2 \%$ has 6-8 and 9-12 years of experience in teaching. The result implies that there are more respondents who are still new in the teaching profession. This finding coincided by the findings in the research of Michael [61] and Escalona [59] where most of their respondents have been in the profession for less than 10 years.

Figure 7 reveals the type of school the respondents are currently employed in.The value on the figure discloses that 80 or $67 \%$ are publicly employed while 31 or $26 \%$ are privately employed. The result is an implication that there was a need for teacher's hiring in 
public school as the turn over became fast. This could be attributed to some factors like retirements of old teachers and teachers who availed optional retirement for personal reasons. The opening of K-12 Curriculum may also be a great factor as the rate of demands in hiring is high in public school.

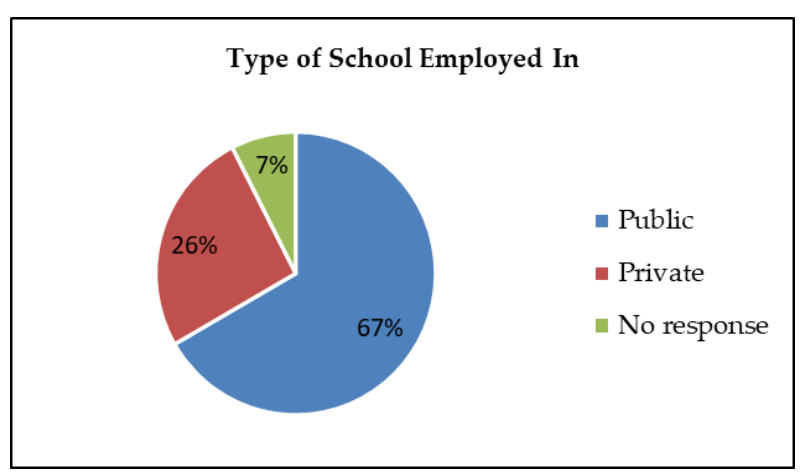

Fig.7 Type of School Employed In

Table 1.a. Level of satisfaction of the respondents on the following Graduate School Services along Professional Services

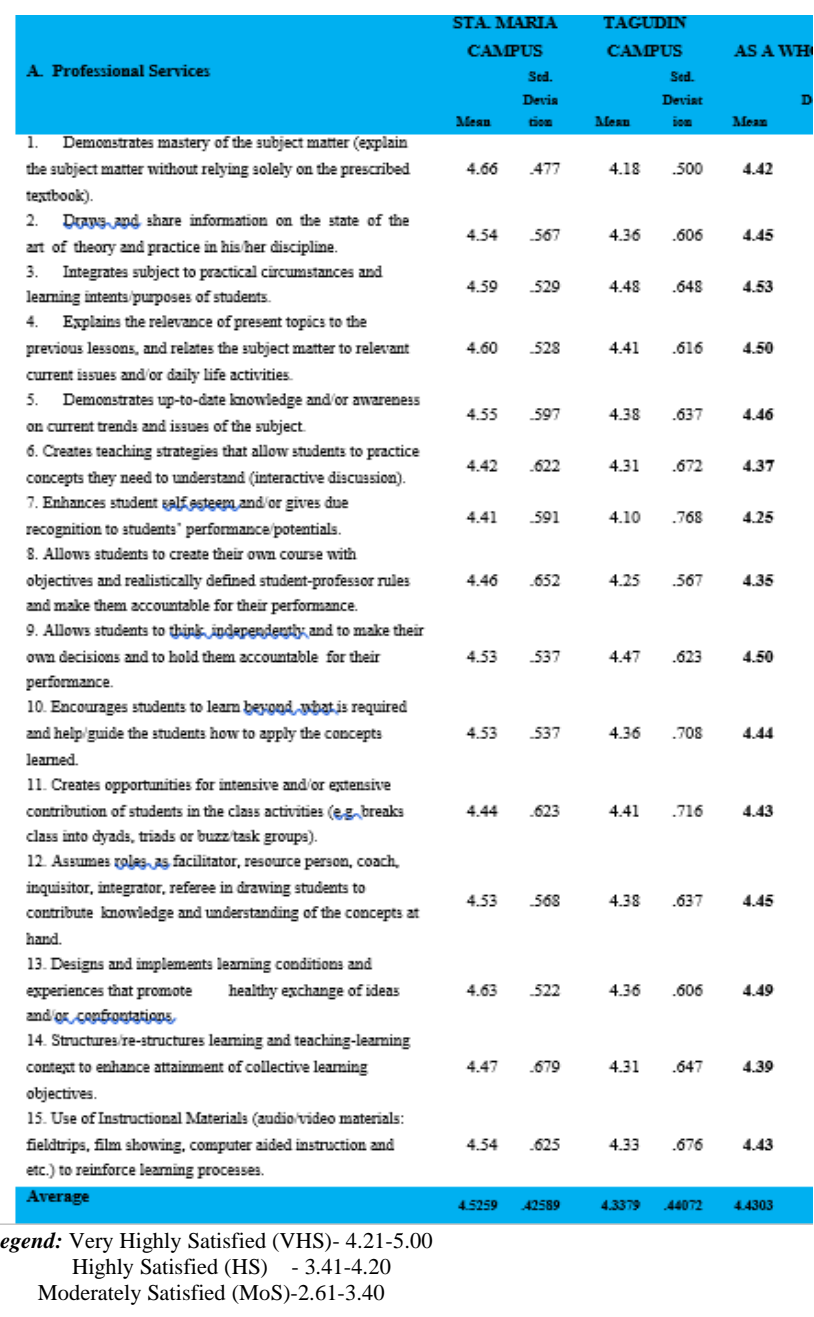

The table discloses that along Professional Services.It can be gleaned on the table that,Integrates subject to practical circumstances and learning intents/purposes of students is the item that receives the highest mean with 4.53 described as Very Highly Satisfied followed by the items Explains the relevance of present topics to the previous lessons, and relates the subject matter to relevant current issues and/or daily life activities and Allows students to think independently and to make their own decisions and to hold them accountable for their performance with a mean of 4.50 described as Very Highly Satisfied also.Taking the lowest mean though received a Very Highly Satisfied rating is the item Enhances student self esteem and/or gives due recognition to students' performance/potentials with a mean of 4.25.

This result indicates that professionally, the students in the graduate school are guided and get the attention that is accorded to them. The explanation and the integration to practical situations of topics during classes is considered by the students as beneficial as they pursue their career in the teaching profession.

This findings reconcile that of Yusoff et al, [48] whose study revealed that professional comfortable environment, student assessment and learning experiences, classroom environment, lecture and tutorial facilitating goods, textbooks and tuition fees, student support facilities, business procedures, relationship with the teaching staff, knowledgeable and responsive faculty, staff helpfulness, feedback, and class sizes make significant impact on students' satisfaction.On the other hand,Butt \& Rehman[62]disclosed in their study that teachers' expertise is the most influential factor among all variables considered in their study.

The link between professional services and students' satisfaction is further elaborated in the study of Mai[45] where the student satisfaction in higher education and its influential factors were studied. It was found out that the over-all impression of the school, overall impression of the quality of the education, teachers expertise and their interest in the subject, the quality and accessibility of IT facilities and the prospects of the degree furthering students careers were the most influential predictors of the students satisfaction.

School Facilities.Among facilities in the Graduate School,the Graduate School Office receives the highest mean of 4.21 described as Very Highly Satisfied followed by classrooms with a mean of 4.05 described as Highly Satisfied.The lowest mean is on item Accessibility of books and computers in the library with a mean of 3.33 described as Moderately Satisfied.This result implies that students consider facilities as factor to their absorption of learning. They feel the need of the provision of books and computer services in the library for their researches.

Table 1.b. Level of satisfaction of the respondents on the following Graduate School Services along School Facilities 


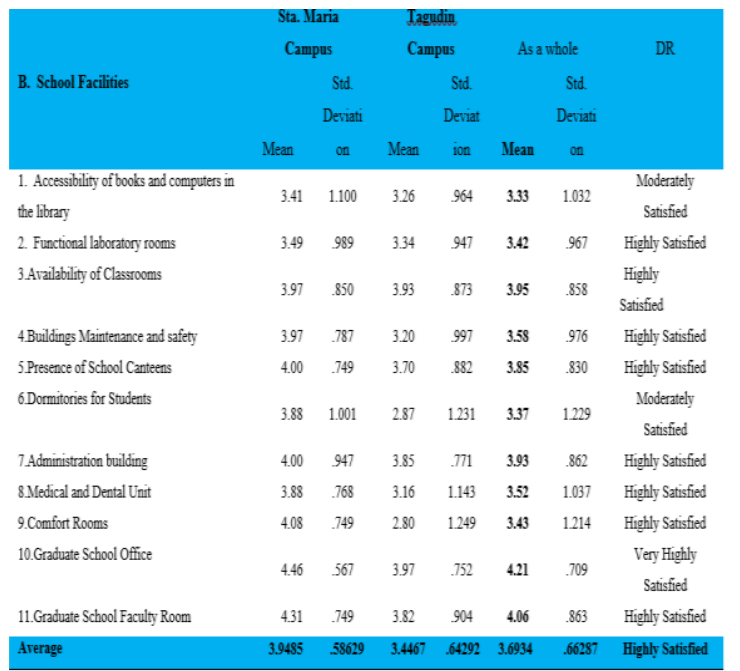

Legend: Very Highly Satisfied(VHS)- 4.21-5.00

Highly Satisfied(HS) $\quad-3.41-4.20$

Moderately Satisfied(MoS)-2.61-3.40

The result of the study clearly negated that of Douglas [64]who measured students' satisfaction on their Higher Education experience using conceptual model. Results revealed that physical facilities of university are not significantly important with regards to students' choice in selecting universities.Martirosyan [63] examined the impact of selected variables on students' satisfaction in Armenia.The study identified reasonable curriculum and faculty services as key factors on student satisfaction. The study also displayed negative relationships of faculty teaching styles and graduate teaching assistants with students' satisfaction. Of the variables considered under demographic profile, type of institution effect on students' satisfaction significantly in which students from private institutions reported a significantly higher satisfaction level than their peers at public institutions.

Learning Environment. As indicated in the table, it clearly projects that the item, Expounds on one's understanding of the learning processes and the role of the teacher in facilitating these processes in their students received the highest mean of 4.33 followed by the item, Reflects on the impact of home and family life to learning both described as Very Highly Satisfied. The lowest mean on the other was received by the item, Determines an environment that provides social, psychological, and physical environment supportive of learning with 4.06 described as Highly Satisfied. This result implies that learners' desire to have an environment that provides holistic development and holistic approach in teaching is well manifested as professors in the Graduate School clearly understand their role as teachers of advanced higher education.
Table 1.c. Level of satisfaction of the respondents on the following Graduate School Services along Learning Environment

\begin{tabular}{|c|c|c|c|c|c|c|c|}
\hline \multirow{4}{*}{ C. Learning Environment } & \multicolumn{2}{|c|}{$\begin{array}{l}\text { STA. MARIA } \\
\text { CAMPUS }\end{array}$} & \multicolumn{2}{|c|}{ TAGUDIN } & \multicolumn{2}{|c|}{ AS A WHOLE } & \multirow{4}{*}{$\mathrm{DR}$} \\
\hline & & Std. & & Std. & & Std. & \\
\hline & & Deviat & & Deviati & & Deviat & \\
\hline & Mean & ion & Mean & on & Mean & ion & \\
\hline $\begin{array}{l}\text { 1. Determines an environment that provides social, } \\
\text { psychological, and physical environment } \\
\text { supportive of leaming. }\end{array}$ & 4.29 & .559 & 3.84 & .583 & 4.06 & .612 & $\begin{array}{l}\text { Highly } \\
\text { Satisfied }\end{array}$ \\
\hline $\begin{array}{l}\text { 2. Differentiates leamers of varied leaming } \\
\text { characteristics and needs. }\end{array}$ & 4.31 & .595 & 3.92 & .526 & 4.11 & .591 & $\begin{array}{l}\text { Highly } \\
\text { Satisfied }\end{array}$ \\
\hline $\begin{array}{l}\text { 3. Manages time, space and resources to provide an } \\
\text { environment conducive to learning. }\end{array}$ & 4.33 & .574 & 4.02 & .671 & 4.17 & .642 & $\begin{array}{l}\text { Highly } \\
\text { Satisfied }\end{array}$ \\
\hline $\begin{array}{l}\text { 4. Recognizes multi-cultural background of } \\
\text { leamers when providing leaming opportunities. }\end{array}$ & 4.31 & .701 & 4.10 & .597 & 4.20 & .656 & $\begin{array}{l}\text { Highly } \\
\text { Satisfied }\end{array}$ \\
\hline $\begin{array}{l}\text { 5. Determines teaching approaches and techniques } \\
\text { appropriate to the leamers. }\end{array}$ & 4.39 & .558 & 4.20 & .654 & 4.29 & .614 & $\begin{array}{l}\text { Very Highly } \\
\text { Satisfied }\end{array}$ \\
\hline $\begin{array}{l}\text { 6. Determines, understands and accepts the } \\
\text { learner's diverse background. }\end{array}$ & 4.36 & .580 & 4.20 & .601 & 4.28 & .594 & $\begin{array}{l}\text { Very Highly } \\
\text { Satisfied }\end{array}$ \\
\hline $\begin{array}{l}\text { 7. Relates the leamers' background to their } \\
\text { performance in the classroom. }\end{array}$ & 4.32 & .571 & 4.16 & .610 & 4.24 & .594 & $\begin{array}{l}\text { Very Highly } \\
\text { Satisfied }\end{array}$ \\
\hline $\begin{array}{l}\text { 8. Reflects on the impact of home and family life } \\
\text { to leaming. }\end{array}$ & 4.41 & .561 & 4.20 & .679 & 4.30 & .630 & $\begin{array}{l}\text { Very Highly } \\
\text { Satisfied }\end{array}$ \\
\hline $\begin{array}{l}\text { 9. Expounds on one's understanding of the } \\
\text { leaming processes and the role of the teacher in } \\
\text { facilitating these processes in their students. }\end{array}$ & 4.47 & .537 & 4.20 & .628 & 4.33 & .599 & $\begin{array}{l}\text { Very Highly } \\
\text { Satisfied }\end{array}$ \\
\hline $\begin{array}{l}\text { 10. Accepts personal accountability to leamers' } \\
\text { achievement and performance. }\end{array}$ & 4.36 & .580 & 4.18 & .646 & 4.27 & .618 & $\begin{array}{l}\text { Very Highly } \\
\text { Satisfied }\end{array}$ \\
\hline Average & 4.3525 & .49283 & 4.1000 & .52186 & 4.2242 & .52131 & $\begin{array}{l}\text { Very Highly } \\
\text { Satisfied }\end{array}$ \\
\hline Oxer all Average Graduate School Services & 4.3017 & .40630 & 4.0002 & .43969 & 4.1484 & .4486 & $\begin{array}{l}\text { Highly } \\
\text { Satisfied }\end{array}$ \\
\hline
\end{tabular}

Along school environment, Malik, et al. [31] found out that cooperation, kindness of administrative staff, responsiveness of the educational system play a vital role in determining students' satisfaction. Along this result, Pathmini, et al [32] also found out that reliability, curriculum and empathy are major determinant factors of student satisfaction in regional state universities.

Over-all, the mean obtained by the Graduate School Services is 4.18 described as Highly Satisfied. This result implies that there is a feeling of confirmation among students particularly on the three services.

This result can be explained by Hatcher, Prus, Kryter and Fitzgerald [35] whose study revealed that students perceive their time, energy and effort as investment and seek a return from that. Carter et al.,[36] findings also conformed that students will be satisfied if they are rewarded in relation to the investment they made.

The findings also corroborated with Jurkowitsch, et al.[22] whose findings revealed that service performance, university performance, relationships with student, university standing works as antecedents of satisfaction and promotion. 
The learning environment can also be viewed from a pedagogical perspective. The pedagogical learning environment covers the pedagogical methods and practices used in the teaching and learning(Silander and Ryymin[65].The learning environment must enable the use of diverse studying and working methods. According to a recent study of Çubukçu,[66], teachers regard the psycho-social dimension as the key factor in the learning environment. This may be because teachers are still unfamiliar with the significance of the physical environment, or feel that they have the least opportunity to influence the physical environment.

Significant Relationship Between The Profile And The Graduate School Services Along Professional Services, Learning Facilities And Learning Environment

Table 2a.Significant Relationship between the Profile and the Graduate School Services along Professional Services, Learning Facilities and Learning Environment

Table 2a. Significant Relationship between the Profile and the Graduate School Services along Professional Services, Learning Facilities and Learning Environment

\begin{tabular}{|c|c|c|c|c|}
\hline Variables & $\begin{array}{l}\text { Professi } \\
\text { onal } \\
\text { Services }\end{array}$ & $\begin{array}{l}\text { School } \\
\text { Facilities }\end{array}$ & $\begin{array}{l}\text { Learning } \\
\text { Environment }\end{array}$ & $\begin{array}{l}\text { Over all } \\
\text { Graduate } \\
\text { School } \\
\text { Services }\end{array}$ \\
\hline Age & .040 & -101 & -.072 & -054 \\
\hline Sex & .179 & .103 & .175 & .177 \\
\hline Years of Teaching Experience & $.203^{\circ}$ & -.179 & -.092 & -028 \\
\hline Type of School Employed in & .041 & .092 & .130 & .098 \\
\hline Position & -139 & $-250^{\circ *}$ & $-357^{\circ "}$ & $-2811^{\prime *}$ \\
\hline Employment Status & .006 & .155 & .092 & .118 \\
\hline
\end{tabular}

**. Correlation is significant at the 0.01 level (2-tailed).

*. Correlation is significant at the 0.05 level (2-tailed).

Table 2a presents the significant relationship between the profile of the respondents and the Graduate School Services. As reflected on the table, Years of Teaching has effect on professional services. Position, on the other hand, has a definite but small relationship to school facilities and learning environment. This result implies that those who have more years in teaching experience has higher regard to Professional Services. Those who are lower in position have higher satisfaction on school facilities and learning environment. Students who have rendered more years in the teaching profession show appreciation on the knowledge and experiences of the professors being manifested in the delivery of their professional services. Younger professional students enrolled in the Graduate School show satisfaction of the facilities.This could be attributed to the newness and the structure of the building being occupied by the Graduate School.

Relative to this finding, the study of Lei [49] revealed that the physical learning environment has an influence on how students experience teaching. When no attention has been paid to the quality of the physical learning environment, students are more dissatisfied with the quality of teaching. More focus should be put on the development of learning environments to make them better support to learning.

Table 2b. Significant Relationship between the Profile and the Graduate School Services along Professional Services, Learning Facilities and Learning Environment Chi square, civil status and dependent variables

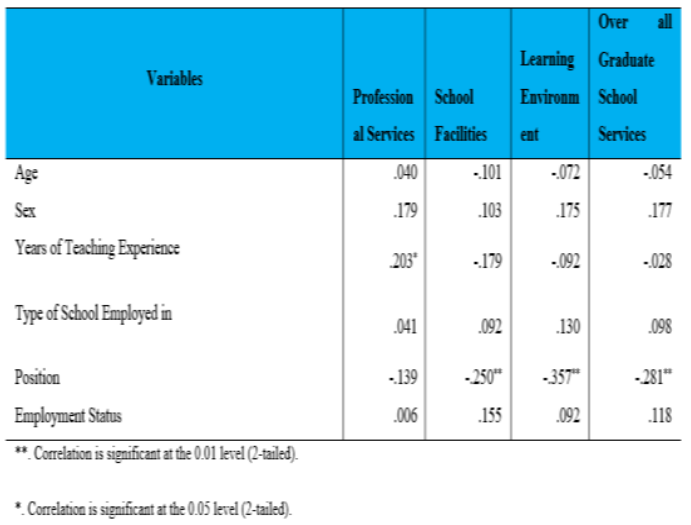

As reflected on table $2 b$,it appeared that all significant values are greater than 0.05 , which means that there is no significant relationship between civil status and the dependent variables. This result implies that the marital status of the respondents has no effect to their level of satisfaction on professional service, learning facilities and learning environment.

Strengths and Weaknesses of Graduate School Services along Facilities

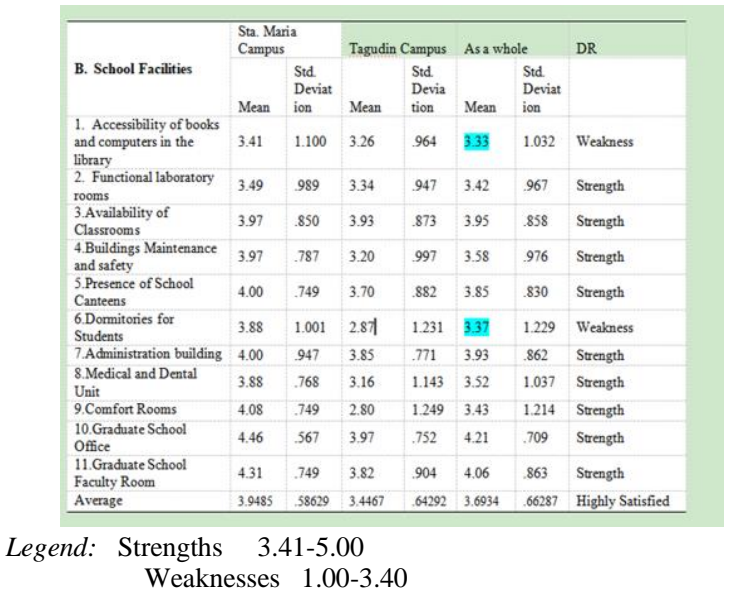

Table 3 discloses the strengths and weaknesses of the Graduate School Services. On Professional Services,all items were rated strengths. On School facilities, two items were regarded as weaknesses 
namely accessibility of books and computers in the library and dormitories for students. Learning Environment, on the other hand, all items appeared as strengths. The three (3) identified weaknesses are considered essential to graduate students. The library holdings such as books and computers are utilized for their researches and other paper works relative to their studies. The study further implies that dormitory services are needed by the graduate students. Considering its populace, there are students who are coming from the remote and mountainous areas of the province who would want to avail dormitory services during weekend classes.

Republic of the Philippines
Main Campus, Santa MIC STATE COLLEGE Ilocos Sur
IMPROVEMENT PLAN
ispsc.edu.ph
I. RATIONALE
The Graduate School of Sta. Maria and Tagudin adheres to the vision of the College, to become
vibrant and nurturing Polytechnic Service College for transforming lives and communities and guided
by its mission, to improve the lives of people and communities through quality instruction, innovations,
productivity initiatives, environment and industry-feasible technologies, resources mobilization and
transformation outreach program and service.
The Graduate School is guided by these goals: a)It should see that its graduates are able to make
use of the basic concepts and trainings in professionals and technical fields,b)They are expected to
become globally competent, responsible and productive professionals who can respond to the needs of
the service area,c)Its graduates have strong research and development capabilities for demand-diven
and environment friendly technologies and d)Its graduates are professionals molded with desirable
values that are contributory to sustainable development.
ISPSC Graduate School regard its students as professionals who seek nurturance of their
academic competence and professional competitiveness, thus, excellent services should be a primary
concem.
This study determined the satisfaction of the students on the services offered by the Graduate
School to come up with a tangible output that is research based to better implement these services to
serve its stakeholders, thus, an Improvement Plan is proposed.
II. OBJECTIVES
A. To establish full access of the library facilities and provide e-library for the students.
B. To improve the accommodation services of the students who come from remote areas.

The findings of this study reconcile with the result obtained in the study of Sapri et al.[67] who examined students' priorities with respect to their satisfaction with facilities services offered at higher educational institutions. The results on students' perspectives about higher education facility services identify the most critical aspects that affect them as education clients.

The identified weaknesses are the benchmark in formulating an Improvement Plan as an output of this study. The output of the study is expected to better the services of the Graduate School along Professional Services, Facilities and Learning Environment. Though the study revealed that over-all, the students are Highly Satisfied with the services provided by the Graduate School of Ilocos Sur Polytechnic State College, still, there is a need to sustain and improve these services to meet the Very Highly Satisfied rating.

Proposed Improvement Plan. A a result of the study, this Improvement Plan is proposed to help improve the services of Ilocos Sur Polytechnic State College Graduate School.

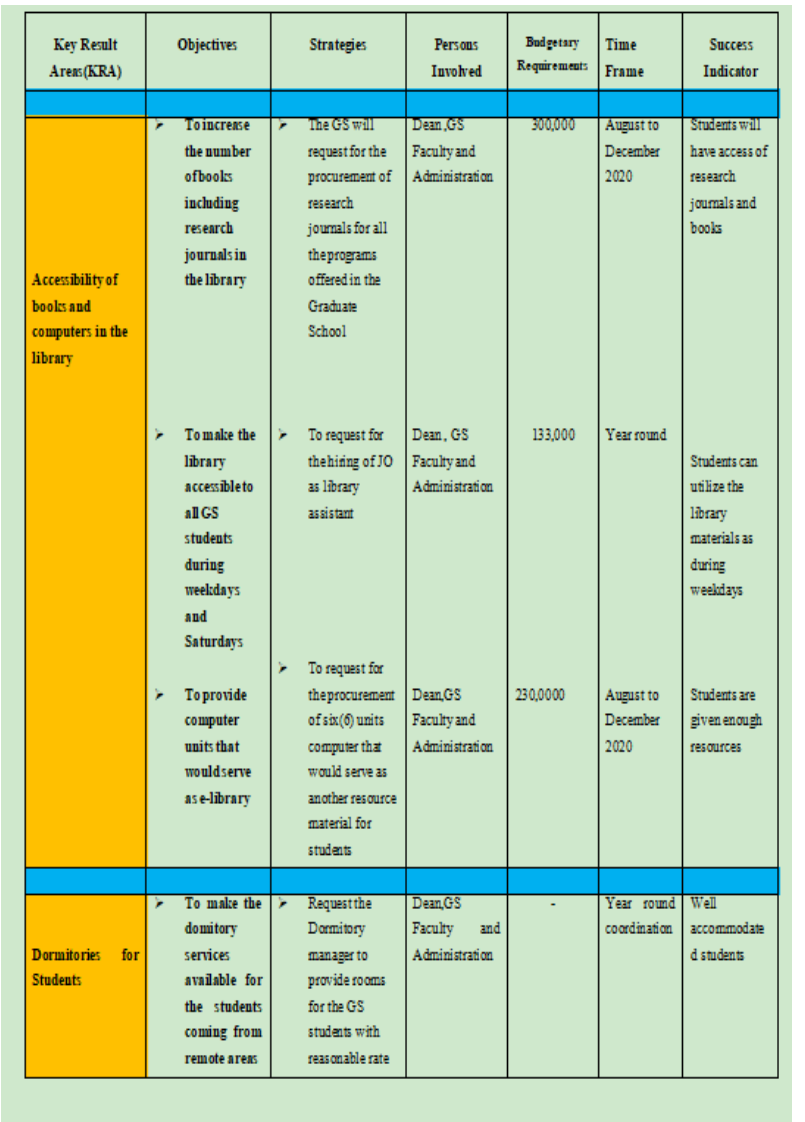

\section{CONCLUSIONS}

The profile projects that students enrolled at the ISPSC Graduate School are mostly female, on the age bracket of 21-25, single, employed in public schools and occupying Teacher 1 position.

The students are highly satisfied with the services offered by the Graduate School.

Years of Teaching displays a relationship on professional services. Position on the other hand has a definite but small relationship to school facilities and learning environment.

The study identified that accessibility of books and computers in the library and dormitories were areas that require improvement.

Improvement Plan is recommended to be implemented.

\subsection{Recommendations}

The students should see the benefits of finishing their Master's degree at a very early stage of their career. The Graduate School shall continue improving its services to provide maximum satisfaction for the clientele. The accessibility of books and the use of dormitory services should be addressed immediately. The implementation of the Improvement Plan shall take effect immediately 


\section{LIMITATIONS AND FUTURE STUDIES}

This study, however, has some limitations. The results have represented students' opinions about advanced higher educational services catered by the College being studied. The results should not be presumed therefore to be true to all HEIs.Nevertheless, results obtained in this study have similarities to the findings of the previous studies conducted. As this study aims to improve the services of the College, results of which have been disseminated for its consideration.For future studies along this topic, other services may be considered to amplify the purpose of measuring stakeholders' satisfaction on Graduate School services.

\section{ACKNOWLEDGMENT}

The researcher expresses her indebtedness to Dr. Francisco D. Lopez(+),former SUC president, of Ilocos Sur Polytechnic State College,Dr. Rogelio T. Galera,Jr.CHED Regional Director,Dr.Gilbert R. Arce,Dr. Gloria Tuzon,Dr. Remely Sanidad, and Dr.Redentor Rojas.

\section{REFERENCES}

[1] CHED Memorandum Order no.53, series of 2007

[2] McGowen, R. S. (2007). The Impact of School on Student Achievement, Attendance, Behavior, Completion Rate and Teacher Turnover Rate in Selected Texas High Schools . Texas: Texas A\&M University.

[3] Vidalakis, C., Sun, M., \& Papa, A. (2013). "The quality and value of higher education facilities: a comparative study". Facilities, 31No.11/12,489504.DOI:10.1108/F- 10-2011- 0087

[4] Athiyaman, A. (1997). Linking student satisfaction and service quality perceptions: The case of university education. European Journal of Marketing, 31(7), 528 540.doi:10.1108/03090569710176655

[5] Orpen, C. (1990). The measurement of student university satisfaction: A consumer behavior perspective. Journal of Human Behavior and Learning, 7, 34-37.

[6] Barton, D. W. (1978). Marketing higher education. San Francisco: Jossey-Bass

[7] Navarro, M. M., Iglesias, M. P. \& Torres, P. R.,( 2005). A new management element for universities: satisfaction with the offered courses. International Journal of Educational Management,19(6),pp.505526. DOI.org/101108/09513540510617454
[8] Elliott, K. M. and Healy, M. A. (2001), "Key factors influencing student satisfaction related to recruitment and retention", Journal of Marketing for Higher Education, Vol. 10 No. 4,pp. 111.https://doi.org/10.1300/J050v10n04_01

[9] Gbadosami \& De Jager (2010). Specific remedy for specific problems: measuring service quality in south African higher education. Higher Education,251-267

[10] Shaatmelau, R. (2015).How Academic Facilities Affects Students Satisfaction with Higher Education Services: A Case Study of SAUT.St.Augustine University of Tanzania.

[11] Oliver, R.L.(1989). Processing of the satisfaction response in consumption: A suggested framework and research propositions. Journal of Consumer Satisfaction, Dissatisfaction, and Complaining Behavior, 2, 1-16.

[12] Oliver, R.L. (1997). Satisfaction: A behavioral perspective on the consumer. Singapore: McGrawHill International Editions.

[13] McDougall, G.H.G, \& Levesque, T. (2000). Customer satisfaction with services: Putting perceived valued into the equation. Journal of Services Marketing, 14(5), 392-410.

[14] Crompton, J. L., \& MacKay, K. J. (1989). Users' perceptions of the relative importance of service quality dimensions in selected public recreation programs. Leisure Sciences, 11(4), 367-375 https://doi.org/10.1080/014904089095 12233

[15] Browne.K.W. \& Brown D., (1998). Student Customer Factors Affecting and Assessments of Institutional Quality. Journal of Marketing Management, 8 (3), 114.DOI:10.1300/JO50v08n03_01

[16] Grossman, Randi P. (1999). Relational Versus Discrete Exchanges: The Role of Trust and Commitment in Determining Customer Satisfaction.. The Journal of Marketing Management(10711988).Vol.9 Issue 2: 47-58.

[17] UNESCO,2011.Retrieved June 13,2021 from https://inee.org/system/files/resources/212715eng. pdf

[18] Ugboma,C. et al. (2007).Service quality and satisfaction measurements in Nigerian ports: An exploration Maritime Policy \& Management 34(4):331346.DOI: 10.1080/0308883 0701539073

[19] Trivellas,P. \& Geraki,A.(2008).Investigating Principals' Leadership Profile in Secondary 
Education.Marketing and Management Sciences-The International Conference on ICMMS.DOI:10.1142/9781848165106_0109

[20] Isani, U. A. G., and Virk, M. L. (2005), "Higher education in Pakistan: a historical and futuristic perspective", Islamabad: National Book Foundation.

[21] Hanaysha, J. , Abdullah, H. and Warokka, A. (2011), "Service quality and students' satisfaction at higher learning institutions: the competing dimensions of Malaysian universities'competitiveness",Journal of Southeast Asian Research, Vol. 1, available at:Www.ibimapublishing.com/journals/JSAR/2011/ 855931/a855931.html

[22] Jurkowitsch, S., Vignali, C. \& Kaufmann, H.-R., (2006). A Student Satisfaction Model of Austrian Higher Education. Innovative Marketing, 2(3), pp. 9-21.

[23] DeShields Jr.,O.W.,Kara,A. and Kaynak E.(2005).'Determinants of business student satisfaction and retention in higher :applying Herzberg's two factor theory",International Journal of Educational Management, 19(2),28139.

[24] Alves, H. \& Raposo, M., (2010). The influence of university image on student behaviour. International journal of Educational Management, pp. 73-85.

[25] Wilkins, S. \& Balakrishnan, M. S., 2013.Assessing student satisfaction in transnational higher education. International Journal of Educational Management, pp. 146-153

[26] Sapri,M., Kaka,A.\&Finch,E.2009. Factors That Influence Student's Level of Satisfaction With Regards To Higher Educational Facilities Services.Malaysian Journal of Real Estate Volume 4 No 1.

[27] Banwet, D. K. and B. Datta (2003). "A dusty of the effect of perceived lecture quality on post-lecture intentions." Work Study 52(4): 234-243.

[28] Hill,Y.,Lomas L.,\& Mc Gregor,J.(2003)Students' perceptions of quality in higher education.Quality Assurance in Education 11:1520.DOI:10.1108/09684880310462047

[29] Kanan, H. M. \& Baker, A. M., 2006. Student satisfaction with an educational administration preparation program. Journal of Educational Administration, 44(2), pp. 159-169.DOI $10.1108 / 09578230210440311$

[30] Palacio, A. B., Meneses, G. D. \& Perez Perez, P. J., 2002. The configuration of the university image and its relationship with the satisfaction of students. Journal of Educational Administration, 40(5), pp. 486-505. DOI $10.1108 / 09578230210440311$

[31] Malik, M. E., Danish, R. Q. \& Usman, A., 2010. The Impact of Service Quality on Students' Satisfaction in Higher Education Institutes of Punjab. Journal of Management Research, pp. 1-11. ISSN 1941-899X 2010, Vol. 2, No. 2: E10

[32] Pathmini, M., Wijewardhena, W., Gamage, C. \& Gamini, L., (2014). Impact of Service Quality on Students' Satisfaction in Newly Established Public Sector Universities in Sri Lanka: Study Based on The Faculty of Management Studies. Journal of Management Matters, pp. 51-64.

[33] Yu,Y. and Dean,A.,(2001) "The contribution of emotional satisfaction to consumer loyalty", International Journal of Service Industry Management,Vol. 12 No. 3, pp. 234-250

[34] Wiers-Jenssen, J., Stensaker, B., \&. Grøgaard, J. B. (2002). Student satisfaction: Towards an empirical deconstruction of the concept. Quality in Higher Education, 8, 183-195.

[35] Hatcher, L., Kryter, K., Prus, J. S, \& Fitzgerald, V. (1992). Predicting college student satisfaction, commitment, and attrition from investment model constructs. Journal of Applied Social Psychology, 22(16), 1273- 1296

[36] Carter, P., Kakimoto, E. \& Miura, K., 2014. Investigating student satisfaction in an English communication course: A pilot study.pp. $57-$ 65

[37] Farahmandian, S., Minavand, H. \& Afshard, M., 2013. Perceived service quality and student satisfaction in higher education. Journal of Business and Management, pp. Volume 12, Issue 4 , PP 65-74

[38] Khan, M. M., Ahmed, I. \& Nawaz, M. M., 2011. Student's Perspective of Service Quality in Higher Learning Institutions; An evidenceBased Approach. International Journal of Business and Social Science, 2(11), pp. 159164

[39] Gruber,T.,Voss,R.,Fub,S.,\&Zikuda,M.(2010).Exa mining Student atisfaction with Higher Education Services: Using A New Measurement Tool.International Journal of Public Sector Management 23(2):105123DOI:10.1108/09513551011022474 
[40] Douglas,J.,A.Douglas,et al.,(2006).”Measuring student satisfaction at UK university." Quality Assurance in Education 14(3): 251-267.

[41] Daigneau, W. A. (2006). Facilities and Educational Quality. Organization for Economic Cooperation and Development. Texas: University of Texas.

[42] Luna,A. and Kanu,E.C.(2019).Student Assessment of Campus Facilities-Spring 2019.Austin Peay State University.

[43] O'Neill, D. (2000). The impact of school facilities on student achievement, behavior, attendance, and teacher turnover rate at selected Texas middle schools in Region XIII ESC. Unpublished doctoral dissertation, Texas

A\&M University, College Station, TX

[44] Maiden, J., \& Foreman, B. (1998). Cost, design and climate: Building a learning environment. School Business Affairs, 64(1), 4044.

[45] Mai,L.W.(2005) A comparative study between UK and US: The student satisfaction in higher education and its influential factors.Journal of Marketing Management,21(7):859.

[46] Kotler,P. and Keller,K.(2006).Marketing Management $12^{\text {th }}$ Edition,Prentice Hall,Upper Saddle River.

[47] Rai,A.K.(2013).Customer Management: Concept and Cases.Delhi:PHI Learning Private Limited.

[48] Yusoff,M,,McLaey,F. \& \& WoodruffeBurto,H.,(2015).Dimensions Driving business student satisfaction in higher education:Quality Assurance in Education,pp.86-104.

[49] Lei,Simon. A.(2010).Classroom physical design influencing students' learning and evaluations of college instructions: a review of literature.Education, Vol 131,number 1(128-134).

[50] Cheng,Y.C., and Tam,M.(1997).Investigating Principals' Leadership Profile in Secondary Education Marketing and Management SciencesThe International Conference on ICMMS. DOI:10.1142/9781848165106_0109

[51] Larkin, H. and Richardson, B. (2013), “Creating high challenge/high support academi environments through constructive alignment: student outcomes", Teaching in Higher Education, Vol. 18 No. 2, pp. 192-204.

[52] Thygesen, H., Gramstad, A., Åsli, L.A., Stigen, L., Magne, T.A., Carstensen, T. and Bonsaksen,
T. (2020), "Associations between learning environment factors and student satisfaction among occupational therapy students", Irish Journal of Occupational Therapy, Vol. 48 No. 2, pp. 91-100. https://doi.org/10.1108/IJOT10-2019- 0015

[53] Thomas, E. H. and Galambos, N. (2004), "What satisfies students? Mining student- opinion data with regression and decision tree analysis", Research in Higher Education, Vol. 45 No. 3, pp. 251-269.

[54] Bernardini,A. \& Conati,C.(2010).Discovering and Recognizing Student InteractionPatterns in ExploratoryLearningEnvironments.DOI:10.1007/9 78-3-642- 13388-6_17.

[55] GautschilII,F.H. \& Jones,T.M.(1998).Enhanci ng the Ability of Business Students to Recognize Ethical Issues: An Empirical Assessment of the Effectiveness of a Course in Business

Ethics. Journal of Business
Ethics volume 17, pages205-216 (1998)Cite this article.

[56] CHED Memorandum No.36,series 1998 Women are outnumbering men at a record high in universities worldwide.Isabelle Bilton.March17,2018.(https://www.studyinternatio nal.com/news /record- high-numberswomen- outnumbering-men- universityglobally/)

[57] Naungayan,R.(2018).TEEPS and SCOPE Program of Banayoyo National High School”.A Master's Thesis,Ilocos Sur PolytechnicState College(Unpublished)

[58] Escalona ,E.(2015).Factors Affecting the NCAE and Mathematics Performance of Fourth Year Students of Candon National High School.A Master's Thesis,Ilocos Sur Polytechnic State College(Unpublished)

[59] DepEd Jobs in the Philippines,Job Vacancies.Retrieved December 28,2020.from(https://www.jobstreet.com.ph/en/job -search/deped-jobs/).

[60] Michael,I.(2015).Factors Leading to Poor Performance in Mathematics Subject in Kibaha Secondary Schools.A Dissertation,Open University of Tanzania.Retrieved on December 18,2020 from repository.out.ac.tz//1293/I/DissertationIsaack's Final.pdf.

[61] Butt B.Z., \& Rehman,K.,(2010).A study examining the students satisfaction in higher 
education. Procedia Social and Behavioral Sciences 2 (2010) 5446-5450

[62] Martrosyan,N.(2015).An examination of factors contributing to student satisfaction in Armenian higher education.International Journal of EducationalManagement. 29(2):177191.DOI:10.11 08/IJEM-09-2013-0143.

[63] Douglas,J.,McClelland,R.J.,\& Davies,J.(2007).The development of a conceptual model of student satisfaction with their experience in higher education. Conference: 11th ICIT Conference TQM \& Corporate Governance Hang Seng School of Commerce Hong Kong
[64] Silander,P., and Ryymin, E.(2012). Oppimisympäristön arviointikehikko oppilaitosjohdolle in. Toim. Silander, P., Ryymin, E., Mattila, P. Tietoyhteiskunnan strateginen johtajuus kouluissa ja opetustoimessa, 49-59

[65] Çubukçu, Z. (2012). Teachers' evaluation of student- centred learning environments. Education, Vol. 133, number 1, 49-66.ISSN-00131172.

[66] Sapri, M., Kaka, A., and Finch, E. (2008). "Higher education students' preferences in relation to library design: a repertory grid analysis." The International Journal of Interdisciplinary Social Sciences, Vol (2):21-30. 